\title{
NEUROLOGICAL RECOVERY DISTAL TO THE ZONE OF INJURY IN I72 CASES OF CLOSED, TRAUMATIC SPINAL CORD INJURY ${ }^{1}$
}

\author{
By John S. Young, M.D. and Wayne R. Dexter, Ph.D. \\ Southwest Regional System for Treatment of Spinal Cord Injury, Good Samaritan Hospital, \\ I033 East McDowell Road, Phoenix, Arizona 85006, U.S.A.
}

Abstract. The Southwest Regional System for Treatment of Spinal Cord Injury (Good Samaritan Hospital and St Joseph's Hospital, Phoenix, Arizona) treated 325 cases of traumatic spinal cord injury during the period June 1970 through December 1975. Of these, I 72 met the study population criteria of the cases reported by Frankel et al. (I969) in their paper 'The value of postural reduction in the initial management of closed injuries of the spine with paraplegia and tetraplegia'. These cases are compared with those reported by Frankel et al. (I969).

Cases were divided into neurological categories. The demography of the two study populations was amazingly similar as was the neurological results. The means for the reported neurological changes show that the average recovery for patients treated at Stoke Mandeville was slightly greater for each neurological category; however, this difference was statistically significant only for cervical cases $(P<0.01)$.

One of the differences in the treatment given by the two centres was that the Southwest Regional System performed surgery on 39 per cent of its cases and Stoke Mandeville none. The Southwest Regional System's non-operated cervical cases showed less average neurological recovery than Stoke Mandeville cervical cases $(\mathrm{P}<0.00 \mathrm{I})$. Comparison between the Southwest Regional System non-operated cases and operated cases revealed no significant differences within any neurological category.

The average neurological change reported by both centres was relatively small, documenting that from the onset of injury the majority of people sustaining spinal cord injury are committed to living with paralysis, in most cases severe, for the rest of their lives.

Key Words: Neurological recovery; Spinal cord injury; Tetraplegia; Paraplegia.

\section{Introduction}

THE Southwest Regional System for Treatment of Spinal Cord Injury was established in Phoenix, Arizona, in 1969. It combines the resources of Barrow Neurological Institute, St Joseph's Hospital with the Spinal Cord Injury Service of Good Samaritan Hospital in a systematised programme of care. The bulk of the acute care (90 per cent) is provided at St Joseph's Hospital, with neurological surgeons serving as primary physicians. The physicians from the Spinal Cord Injury Service of Good Samaritan Hospital serve as consultants during this period. Patients are transferred to the Spinal Cord Injury Service, Good Samaritan Hospital, under the care of full-time spinal cord injury specialists within I to 5 weeks of injury. Following initial discharge, the Spinal Cord Injury Center at Good Samaritan Hospital provides on-going primary care in the form of health

1 This project was supported in part by U.S. Department of Health, Education and Welfare, Rehabilitation Services Administration, Grant Number I3-P-55258/9. 
maintenance services and rehospitalisation for approximately 70 per cent of its cases.

An integral part of the treatment system is the bi-monthly, interspeciality physician conference which serves as an excellent peer review and in-service educational mechanism. The clinical management of each new injury is reviewed and freely discussed. Follow-up reports on appropriate cases are also presented and discussed.

The Southwest Regional System (SWRS) received a grant from the Rehabilitation Services Administration of the United States Government in 1970 to demonstrate a regional system of spinal cord injury treatment. Among other things, it was charged with the responsibility of keeping data relevant to spinal cord injury. It was at that time that Frankel et al. (1969) published the paper 'The value of postural reduction in the initial management of closed injuries of the spine with paraplegia'. They reported on 6I2 patients treated at the National Spinal Injuries Centre, Stoke Mandeville Hospital, between March I95I and August I968. Postural reduction was used in the treatment of all cases. Neurological recovery was reported in terms of neurological grades defined as: A-Complete, B-Sensory only, C-Motor useless, D-Motor useful and E-Recovery. The Southwest Regional System has used these grades to document the neurological recovery in its patients since 1970 .

This paper compares the neurological recovery below the zone of injury observed in 172 patients treated in the Southwest Regional System during the period of June 1970 through December 1975 with data reported by Stoke Mandeville.

\section{Method}

\section{Demography}

During the above period 325 cases of traumatic spinal cord injury were treated in the Southwest Regional System. To match the Stoke Mandeville study, we excluded penetrating injuries, deaths, and admissions greater than I4 days from injury. The resultant $\mathrm{I} 72$ cases comprise the study population for this paper. The neurological status of each case was observed for at least 12 weeks. Cauda equina cases (nine) were omitted from our statistical analysis in that they were few in number and had variable patterns of neurological impairment.

The time from onset of the injury to admission to either St Joseph's Hospital or Good Samaritan Hospital was reasonably short. Fourteen days was used as a criterion for selection of patients for this study in order to match the Stoke Mandeville study. Only i 8 per cent of the cases reported here were admitted over 72 hours from injury. The mean for this group was 7 days. Seventy per cent of our reported cases were admitted within 24 hours of injury. The mean for this group was $6 \cdot 4$ hours.

The aetiology of injury (Table I) reported by both centres is surprisingly similar. It should be noted that Stoke Mandeville reported aetiology on all cases admitted. The data for the Southwest Regional System include only the cases qualifying for this study. Our third largest group, gunshot wounds (40 cases), was eliminated by the study population criteria. In our total admissions, including gunshot wounds, injury resulting from road accidents was 54.8 per cent.

The distribution of cases by neurological category (Table II) was different between the two centres. The Southwest Regional System had a higher per- 
TABLE I

Aetiology of injury

\begin{tabular}{|c|c|c|}
\hline & SWRS & Stoke \\
\hline All road accidents & $63 \cdot 2$ & $49 \cdot 9$ \\
\hline Auto & $54 \cdot 6$ & $26 \cdot 7$ \\
\hline Motorcycle & $7 \cdot 4$ & $16 \cdot 6$ \\
\hline Bicycle and other & $0 \cdot 6$ & $3 \cdot 5$ \\
\hline Pedestrian & 0.6 & $3 \cdot I$ \\
\hline Falls & $\mathrm{I} 7 \cdot 8$ & $25 \cdot 7$ \\
\hline Falling or moving objects & $3 \cdot I$ & $10 \cdot 7$ \\
\hline Sport & $12 \cdot 9$ & 10.4 \\
\hline Other & $3 \cdot 0$ & $3 \cdot 3$ \\
\hline
\end{tabular}

centage of cervical injuries and a lower percentage of dorsal and dorso-lumbar injuries. Because of these differences, comparisons of the outcome of the two centres were made only within neurological categories.

The ratio of complete injuries to incomplete injuries at time of admission within each category was amazingly comparable. The percentage of complete injuries was 52 per cent cervical, 87 per cent dorsal and 70 per cent dorso-lumbar for the Southwest Regional System, and 56 per cent, 8I per cent and 62 per cent respectively for Stoke Mandeville.

\section{Method of Treatment}

The method of treatment followed by the Southwest Regional System is a combination of postural reduction and neurological and/or orthopaedic surgical intervention in selected cases. Patients were maintained in alignment on Stryker turning frames or Stoke-Egerton beds. Cervical injuries were usually treated in skeletal traction with weights frequently exceeding $20 \mathrm{lb}$ for reduction and approximately io $\mathrm{lb}$ thereafter for immobilisation. Halo traction and immobilisation was used in a few cases with unstable fractures associated with grossly incomplete lesions.

Almost all patients were immobilised for periods ranging from 4 to 8 weeks

\section{TABLE II}

Cases by neurological category on admission

\begin{tabular}{lrrrr}
\hline \multirow{2}{*}{$\begin{array}{c}\text { Neurological } \\
\text { category }\end{array}$} & \multicolumn{2}{c}{ SWRS } & \multicolumn{2}{c}{ Stoke } \\
\cline { 2 - 4 } & $N$ & $\%$ & & $\%$ \\
\hline Cervical & 95 & 55 & 2 I 8 & 35 \\
TI-TIO & 38 & 22 & I66 & 27 \\
TII, TI2, LI & 30 & I8 & 205 & 34 \\
Cauda Equina & 9 & 5 & 23 & 4 \\
$\quad$ Total & I72 & I00 & 612 & I00 \\
\hline
\end{tabular}


TABLE III

Operated cases

\begin{tabular}{|c|c|c|c|c|c|c|c|}
\hline & \multirow{2}{*}{$\begin{array}{l}\text { Neuro-category } \\
\text { (total cases) }\end{array}$} & \multicolumn{2}{|c|}{ Laminectomy } & \multicolumn{2}{|c|}{ Fusion ${ }^{\star}$} & \multicolumn{2}{|c|}{ Total } \\
\hline & & $N$ & $\%$ & $N$ & $\%$ & $N$ & $\%$ \\
\hline Cervical & (95) & 9 & I0 & 26 & 27 & 35 & 37 \\
\hline Ti-Tio & (38) & IO & 26 & 0 & 0 & IO & 26 \\
\hline TII, TI2, LI & (30) & I 8 & 60 & I & 3 & I9 & 63 \\
\hline All levels & (I63) & 37 & 23 & 27 & I7 & 64 & 39 \\
\hline
\end{tabular}

* Laminectomy and fusion included in laminectomy.

and then fitted up in a brace or collar which was maintained to the I2th to I 5 th week. Functional X-rays were taken at 12 weeks unless contra-indicated by the nature of the fracture.

Cases selected for surgery are reported by neurological category and type of operation in Table III. Thirty-nine per cent of all cases were operated, which means the bulk of our cases (6I per cent) were treated by postural reduction alone.

Steroids, usually in the form of dexamethasone, were given to 102 of the I63 reported cases $(62.6$ per cent) with most of these being in the group admitted less than 24 hours from injury.

\section{Results}

The data on neurological status on admission and discharge for all cases in this study, along with comparable data reported by Stoke Mandeville, are presented in Tables IV, V, and VI. In each table the 'Frankel grade', documented at the time of admission, is recorded in the appropriate row labelled $\mathrm{A}$ through $\mathrm{E}$ at the left of the grid. The grade at discharge is recorded in the appropriate column labelled $\mathrm{A}$ through $\mathrm{E}$ above the grid. The numbers of cases whose neurological status remained unchanged are represented within the diagonal cells outlined in heavy lines. Cells above and to the right of the heavy lines contain the numbers of cases which improved. Cells below and to the left contain cases which deteriorated.

To summarise these data and thus allow for comparisons between the two centres, the relative change in neurological status between admission and discharge was calculated for each case represented. The net average change was determined by subtracting the total number of grades lost from the total number of grades gained and dividing by the number of patients in each category. Table VII presents the means and standard deviations for changes in neurological grades for the three neurological levels. Within each level the variability in neurological changes observed at the two centres is quite similar. The means for these changes show that the average recovery for patients treated at Stoke Mandeville was slightly greater for each category; however, this difference is statistically significant only for cervical cases $(\mathrm{P}<0 \cdot 0 \mathrm{I})$.

As shown in Table VIII, patients treated at both centres had a similar distribution of severe injuries (grades A and B) and less severe injuries (grades C, D and 
TABLE IV

Cervical injuries

\section{STOKE MANDEVILLE}

\section{SOUTHWEST REGION}

\begin{tabular}{c|c|c|c|c|c|}
\multicolumn{1}{c}{$A$} & \multicolumn{1}{c}{$B$} & $C$ & $D$ & $E$ \\
\cline { 2 - 6 }$A$ & 81 & 21 & 10 & 11 & 0 \\
\hline$B$ & 3 & 9 & 2 & 14 & 5 \\
\hline$C$ & 0 & 1 & 4 & 11 & 5 \\
\hline$D$ & 0 & 0 & 0 & 30 & 11 \\
\hline E & 0 & 0 & 0 & 0 & 0 \\
\hline
\end{tabular}

\begin{tabular}{|c|c|c|c|c|c|}
\hline & A & B & C & D & $E$ \\
\hline A & 41 & 6 & 1 & 1 & 0 \\
\hline$B$ & 0 & 4 & 2 & 10 & 0 \\
\hline C & 0 & 0 & 2 & 3 & 0 \\
\hline D & 1 & 0 & 0 & 14 & 6 \\
\hline $\mathbf{E}$ & 1 & 0 & 0 & 3 & 0 \\
\hline
\end{tabular}

TABLE V

TI-Tıо injuries

STOKE MANDEVILLE

SOUTHWEST REGION
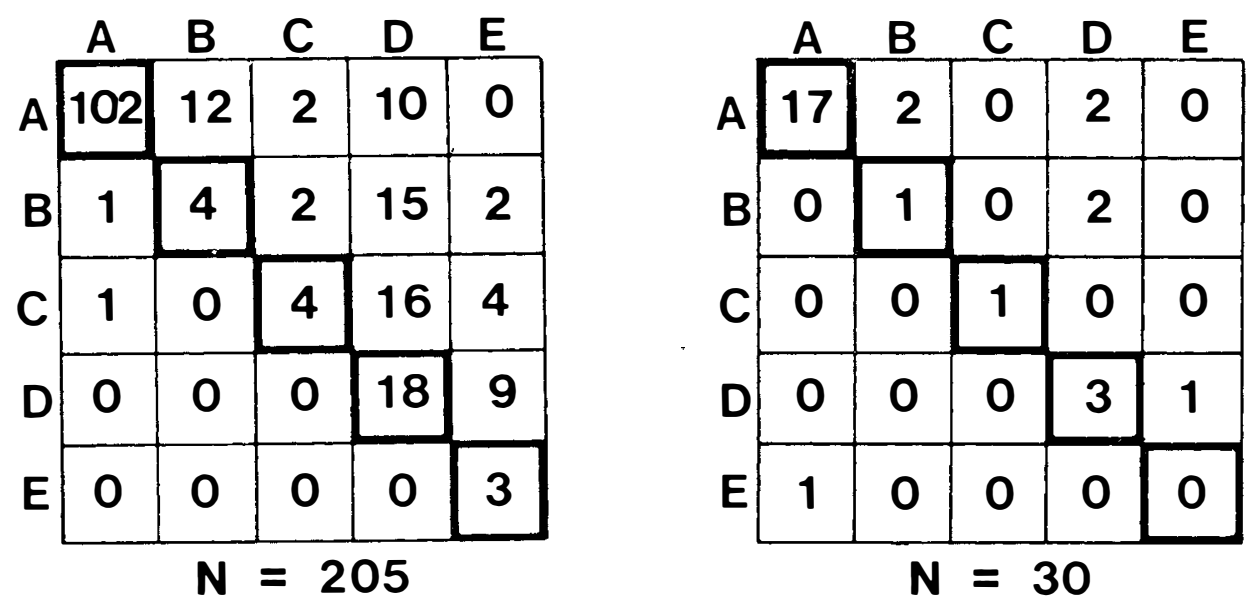

E) at the time of admission. Stoke Mandeville had a slightly higher percentage of severe injuries in the cervical category and a slightly lower percentage of severe injuries in the dorsal and dorso-lumbar categories. As mentioned previously, the ratio of complete injuries to incomplete was markedly similar for both centres.

A major difference in the method of treatment followed by the two centres 
TII, TI2, L. I injuries

\section{STOKE MANDEVILLE}

SOUTHWEST REGION

\begin{tabular}{|c|c|c|c|c|c|}
\hline & A & B & C & D & $E$ \\
\hline A & 114 & 11 & 2 & 7 & 1 \\
\hline B & 0 & 6 & 2 & 5 & 2 \\
\hline C & 0 & 0 & 1 & 1 & 0 \\
\hline D & 0 & 0 & 0 & 4 & 9 \\
\hline$E$ & 0 & 0 & 0 & 0 & 1 \\
\hline
\end{tabular}

\begin{tabular}{|c|c|c|c|c|c|}
\hline & A & B & C & D & $E$ \\
\hline$A$ & 28 & 4 & 1 & 0 & 0 \\
\hline$B$ & 0 & 0 & 0 & 2 & 0 \\
\hline C & 1 & 0 & 0 & 1 & 0 \\
\hline D & 0 & 0 & 0 & 1 & 0 \\
\hline$E$ & 0 & 0 & 0 & 0 & 0 \\
\hline
\end{tabular}

TABLE VII

Change in neuro-grades between admission and discharge

\begin{tabular}{|c|c|c|c|c|c|c|c|c|}
\hline & \multicolumn{3}{|c|}{ Southwest region } & \multicolumn{3}{|c|}{ Stoke Mandeville } & \multirow[t]{2}{*}{$t$} & \\
\hline & $\mathrm{M}$ & S.D. & $N$ & M & S.D. & $N$ & & \\
\hline Cervical & 0.34 & 0.96 & 95 & 0.67 & 0.98 & 218 & $2 \cdot 75$ & $\mathrm{P}<0.0 \mathrm{I}$ \\
\hline TI-TIO & 0.24 & 0.70 & 38 & $0.4 \mathrm{I}$ & 0.85 & I66 & $\mathrm{I} \cdot \mathrm{I} 4$ & N.S. \\
\hline TII, TI2, LI & 0.30 & $\mathrm{I} \cdot \mathrm{I} 9$ & 30 & 0.56 & 0.92 & 205 & $I \cdot 38$ & N.S. \\
\hline
\end{tabular}

TABLE VIII

Neurological status on admission (all cases)

\begin{tabular}{|c|c|c|c|c|}
\hline & \multicolumn{2}{|c|}{ Grades A \& B } & \multicolumn{2}{|c|}{ Grades $\mathrm{C}, \mathrm{D}, \mathrm{E} \mathrm{E}$} \\
\hline & $N$ & $\%$ & $N$ & $\%$ \\
\hline Cervical & $-\cdots$ & $-\cdots$ & - & $\cdots$ \\
\hline $\begin{array}{l}\text { SWRS (95) } \\
\text { Stoke (2I8) }\end{array}$ & $\begin{array}{r}65 \\
156\end{array}$ & $\begin{array}{l}68 \\
72\end{array}$ & $\begin{array}{l}30 \\
62\end{array}$ & $\begin{array}{l}32 \\
28\end{array}$ \\
\hline $\begin{array}{l}\text { TI-TIO } \\
\text { SWRS (38) } \\
\text { Stoke (I66) }\end{array}$ & $\begin{array}{r}35 \\
150\end{array}$ & $\begin{array}{l}92 \\
90\end{array}$ & $\begin{array}{r}3 \\
16\end{array}$ & $\begin{array}{r}8 \\
20\end{array}$ \\
\hline $\begin{array}{r}\text { TII, TI2, LI } \\
\text { SWRS (30) } \\
\text { Stoke (205) }\end{array}$ & $\begin{array}{r}24 \\
150\end{array}$ & $\begin{array}{l}80 \\
73\end{array}$ & $\begin{array}{l}6 \\
55\end{array}$ & $\begin{array}{l}20 \\
27\end{array}$ \\
\hline
\end{tabular}


is the utilisation of surgery by the Southwest Regional System. Thirty-nine per cent of its cases were operated. None were operated at Stoke Mandeville. It was deemed appropriate to direct further analysis to the operated and nonoperated groups. A comparison of the means reflecting neurological change between the Southwest Regional System's non-operated cervical cases and Stoke Mandeville cervical cases was again found to be statistically significant with the Stoke Mandeville's patients showing greater average recovery $(t=3 \cdot 28$, d.f. $=684$, $\mathrm{P}<0.001)$. Comparisons of neurological changes between the Southwest Regional System's non-operated and operated cases revealed no significant differences within any neurological level ( $P>0.05)$.

Table IX presents the figures representing neurological status at the time of discharge for patients admitted with complete injuries. Even with combined grades, the numbers are too small to permit statistical analysis. However, within the cervical category, only I 7 per cent (2I cases) of the Stoke Mandeville patients showed return of motor function, and only 4 per cent (two cases) from the Southwest Regional System showed this degree of recovery. For the other neurological levels, the degree of recovery of motor function in complete lesions observed by the two centres was similarly grim.

\section{Discussion}

The study populations reported by Stoke Mandeville and by the Southwest Regional System were markedly similar, particularly in that they represent cases from two countries with occurrence of injury spanning a period of almost 25 years. Only the distribution of admissions by neurological category differed appreciably. This did not compromise comparison of these data since comparisons were made only within neurological categories.

The neurological grades arbitrarily selected by Frankel et al., though relatively crude, are quite adequate for reflecting meaningful changes in neurological status. Further, these grades can be identified clinically with little difficulty, providing reasonably reliable classification and comparison. Separation of 'motor

\section{TABLE IX}

Neurological status on discharge patients admitted with 'complete' injuries

\begin{tabular}{|c|c|c|c|c|}
\hline & \multicolumn{2}{|c|}{ Grades A \& B } & \multicolumn{2}{|c|}{ Grades $C, D, \& E^{\star}$} \\
\hline & $N$ & $\%$ & $N$ & $\%$ \\
\hline \multicolumn{5}{|l|}{ Cervical } \\
\hline SWRS (49) & 47 & 96 & 2 & 4 \\
\hline Stoke (123) & 102 & 83 & $2 \mathrm{I}$ & I7 \\
\hline \multicolumn{5}{|l|}{ Ti-Tio } \\
\hline SWRS (33) & 32 & 97 & I & 3 \\
\hline Stoke (135) & 125 & 93 & IO & 7 \\
\hline \multicolumn{5}{|l|}{ TII, TI2, LI } \\
\hline SWRS (2I) & I9 & 90 & 2 & IO \\
\hline Stoke (I26) & II 4 & 90 & I2 & IO \\
\hline
\end{tabular}

$\star$ No cases had complete recovery (E). 
useless' (C) cases from 'motor useful' (D) occasionally requires an arbitrary decision and is therefore a potential source of bias. A statistical analysis of neurological recovery based on averages has clinical limitations. It is a measure of general, overall results, but not of specific results in a single patient. Clinicians should be wary of interpreting deviation from the mean in an individual case as representing a therapeutic triumph or a clinical calamity.

Recovery of neurological function is but one of the measures of the clinical treatment given to the spinal cord injured. However, it is a dramatic issue and quite understandably commands keen interest on the part of clinicians and research scientists involved in spinal cord injury care. Unfortunately, it is not completely clear whether the degree of neurological recovery is a measure of the treatment given or of the extent of damage inflicted upon the spinal cord at the instant of injury. It is most probably a measure of the summation of both factors. The similarity in results reported by the Southwest Regional System and Stoke Mandeville supports this hypothesis.

Authors reporting 'results of treatment' must be mindful that they are actually reporting the results of their treatment superimposed on naturally occurring neural recovery. It is important that we accumulate a sizeable documentation of neurological recovery in the human clinical model to establish the norm from which deviations, representing the effects of specific treatment, can be ascertained. The Stoke Mandeville study, supplemented by papers presented at the Joint Meeting of the International Medical Society of Paraplegia and the Veterans Administration in Scottsdale, Arizona, 1973, Frankel et al. (1977a, b), Paeslack et al. (1977), combined with this study represent steps in this direction.

Patients treated at Stoke Mandeville fared somewhat better than those treated by the Southwest Regional System in the dorsal and the dorso-lumbar groups and statistically significantly better in the cervical group. No doubt there are some who will interpret these figures as saying, 'surgery is contra-indicated in spinal cord injury'. The authors wish to emphatically state that this is not their interpretation. Many factors have contributed to the total treatment outcome. It must be remembered that 6I per cent of the Southwest Regional System's cases were treated with postural reduction alone. The figures comparing the operated group with the non-operated group treated within the Southwest Regional System show about the same degree of average neurological recovery. Neither group did as well as cases treated at Stoke Mandeville. Non-operated cervical cases in the Southwest Regional System showed significantly less average recovery than cervical cases treated at Stoke Mandeville. These findings suggest that the non-surgical aspects of management provided by the Southwest Regional System were less productive in terms of average neurological recovery. Stated very simply, perhaps Stoke Mandeville Hospital did a better job of conservative management. This could have resulted from a number of factors. Among them are:

I. The organisational differences between the two systems of care. The Stoke Mandeville treatment was provided in one institution by physicians, nurses, therapists, etc. who specialise only in spinal cord care. The Southwest Regional System divides the initial treatment into two segments, the first being provided in a neurosurgical hospital with special interest in spinal cord injury. The second segment of initial care is provided by the Spinal Cord Injury Service at Good Samaritan Hospital which is within a Rehabilitation Institute. The specific contribution of this organisational difference can only be speculative in that it is immeasurable. 
2. The degree of maturation of the two centres. The Spinal Cord Injury Centre was established at Stoke Mandeville Hospital in 1944, 7 years prior to the admission of the first case reported by their study. The Southwest Regional System was established in 1969 , I year prior to the admission of its first reported case. A spinal cord injury treatment programme represents the composite of the individual experiences and professional skills of its treating team, plus the manner in which these individuals communicate and work as a coordinated team. It could be postulated that patients treated in the Southwest Regional System towards the end of the reporting period fared better than those treated earlier. This postulate will be tested next year by comparing our 1970-73 cases with those treated in $1975-77$.

3. Time interval from onset of injury to admission. The time from injury to admission was relatively short for patients treated in the Southwest Regional System. Unfortunately, the Stoke Mandeville Study does not present data from which comparisons can be made. The earlier the admission, particularly when the mean approaches 4 to 6 hours, the greater the possibility for admitting patients that are still in the process of traumatic neurological degeneration. The possible effects of this observation remain unknown and cannot be tested.

4. Degree of skeletal traction. The observed difference in neurological outcome in the cervical injury group may have resulted from such a simple thing as the extent and duration of skeletal traction. Reportedly Stoke Mandeville rarely exceeds $20 \mathrm{lb}$ during reduction. Cases in the Southwest Regional System frequently had weights exceeding $20 \mathrm{lb}$ during reduction. Conceivably, this could result in increased tension on the traumatised cord producing further neural damage. This hypothesis could be tested using carefully matched cases. This we will attempt to do.

The above are some of the factors that may have contributed to the difference in results between the two centres. They would be relevant, particularly to the cervical cases which, because of spinal mobility and lack of supporting structures, are more susceptible to management misadventures. However contributory they may or may not have been, they are unrelated to whether the patient did or did not have surgery.

Neurological recovery distal to the injury, the single comparison made in this paper, is not the only goal of surgery. Changes in neurological function immediately above, below, and within the zone of injury, is a consideration. Documentation, in terms of both detail and reliability, was inadequate in our series to address this issue. Evidently Stoke Mandeville had the same problem. Meaningful information pertaining to neurological changes at the interface awaits a carefully defined and controlled prospective study. Many interacting variables are involved, requiring a large study population.

It may be postulated that early surgical realignment and stabilisation permits early mobilisation, which in turn reduces medical complications and enhances training and psychological and social adjustment. This would also reduce the length of initial hospitalisation, resulting in reduced medical costs. These hypotheses may be quite valid. The authors will attempt to test them and report the findings in a subsequent paper.

As mentioned previously, average neurological change does not necessarily reflect what has happened in an individual case. Some individuals may be considerably helped by appropriate surgery. The results of this study suggest we need to take a closer look at our indications for surgery and to sharpen our diagnostic acumen to improve the selection process. It seems logical that this degree

$$
\mathrm{I} 6 / \mathrm{I}-\mathrm{D}
$$


of sophistication can be attained only in a medical complex which has an organised system of spinal cord injury care and a high spinal cord injury admission rate.

\section{Conclusion}

The results of these two comparable studies are sobering. An important lesson to be learned stems not from their differences, but from their striking similarities. In the cervical group, the only one in which there was a statistically significant difference, there was only one-third of a grade between the reported neurological outcomes. The Southwest Regional System's cases in this category improved only one-third of a grade. The Stoke Mandeville patients improved two-thirds of a grade. Of the 49 patients admitted to the Southwest Regional System with complete cervical injuries, only one patient regained useful motor function. Stoke Mandeville reported 123 cases in this group, II of which regained useful motor function. The outcome in the other neurological categories is similarly grim.

If improvement in neurological function was the only goal in spinal cord injury treatment, those who have devoted their professional lives to the care of the spinal cord injured would be in a state of chronic frustration and despair. These studies clearly document that from the onset of injury the bulk of our patients are committed to living with paralysis, in most cases severe, for the rest of their lives.

Fortunately there are other goals in spinal cord injury care. We can look after these people and keep them healthy. We can help them circumvent physical limitations. We can help them adjust psychologically and socially in order to better cope with the stresses of a new life style. We can even help some of them to be employed. After having done these things, we will have the pleasure of seeing the majority of them living meaningful, purposeful lives. The dramatic events of the acute injury may command the spotlight, but a more rewarding drama unfolds after the curtain goes down.

\section{RÉSUMÉ}

Au Système Régional du Sud-Ouest pour le Traitement des Blessures au Cordon Médulaire (les hôpitaux Good Samaritan et St Joseph, Phoenix, Arizona) on a soigné 325 cas de blessure traumatique au cordon médulaire depuis juin I970 jusqu'à la fin décembre 1975. Parmi ceux-ci, I72 se conformaient au critère du groupe étudié pour les cas rapportés par Frankel et al. (1969) dans leur mémoire 'La Valeur de la réduction posturale pendant le traitement initial des blessures fermées à la colonne vertébrale avec paraplégie'. On compare ces cas avec ceux rapportés par Frankel et al. (I969).

Les cas se sont divisés en catégories neurologiques. La démographie des deux groupes étudiés aussi bien que les résultats neurologiques étaient remarquablement semblables. Les moyennes des changements neurologiques rapportées donnent une moyenne de guérison un peu plus élévée pour les malades soignés à Stoke Mandeville pour chaque catégorie neurologique; cependant, cette différence ne produisait une statistique signicative que pour les cas cervicaux $(P<0 \cdot 0 I)$.

Une différence de traitement donné par les deux centres était qu'au Système Régional du Sud-Ouest on s'est servi de la chirurgie pour 39 pour cent de ces cas tandis qu'à Stoke Mandeville on n'en est pas servi du tout. Les cas cervicaux non-opérés au Système Régional du Sud-Ouest donnent une moyenne plus basse de guérison neurologique que les cas pareils chez Stoke Mandeville $(\mathbf{P}<0.001)$. Les cas opérés en comparaison des cas non-opérés n'ont démontré aucune différence signifiante dans toute catégorie neurologique au Système Régional du Sud-Ouest.

La moyenne de changement neurologique rapportée par les deux centres était relativement petite, ce qui documente que dès l'abord de la blessure, la majorité des gens blessés 
au cordon médulaire ne peuvent pas s'échapper à la paralysie, une paralysis sévère pour la plupart, pour ce qui reste de la vie.

Les événements dramatiques de la blessure traumatique peuvent dominer la scène au début, mais une drame plus importante se déroule après la tombée du rideau.

\section{ZUSAMMENFASSUNG}

Die Resultate dieser zwei vergleichbaren Studien sind ernüchternd. Eine Lehre lässt sich nicht aus ihren Verschiedenheiten, sondern aus ihren verblüffenden Aehnlichkeiten ziehen. In der Gruppe der Halswirbelverletzten-die einzige, in der sich eine statistisch signifikante Differenz ergab-war der Unterschied der neurologischen Erholung lediglich ein Drittel Grad. Die Southwest Regional System-Patienten dieser Kategorie verbesserten sich nur um ein Drittel Grad. Diejenigen von Stoke Mandeville verbesserten sich un zwei Drittel Grad. Von 49 Patienten, die mit einer kompleten Tetraplegie in das Southwest Regional System eingewiesen wurden, gewann nur einer etwas funktionell brauchbare Motorik zurück. Stoke Mandeville verzeichnete I23 Fälle in dieser Gruppe, wovon II funktionell brauchbare Motorik zurückgewannen. Das Resultat der neurologischen Erholung in den übrigen Gruppen ist gleicherweise düster.

Wäre neurologische Erholung das einzige Ziel in der Behandlung von Rückenmarksverletzten, müssten diejenigen, die ihr Berufsleben für diese Patienten einsetzen, in einem Zustand dauernder Frustration und Verzweiflung sein. Diese Studien zeigen klar, dass der Grossteil unserer Patienten vim Unfall her dazu verurteilt sind, mit einer-in vielen Fällen schweren-Lähmung zu leben.

Glücklicherweise gibt's andere Ziele in der Behandlung von Querschnittsgelähmten. Wir können uns um diese Menschen kümmern und sie gesund erhalten. Wir können ihnen helfen, ihre körperlichen Einschränkungen zu überwinden. Wir können ihnen helfen, sich psychisch zu adaptieren und gesellschaftlich $\mathrm{zu}$ integrieren und so besser mit den Anforderungen des neuen Lebensmodus fertig zu werden. Wir können sogar einigen von ihnen helfen, eine Arbeit zu finden. Nachdem wir all dies getan haben, bleibt uns das Vergnügen zu sehen, wie die meisten von ihnen ein sinnvolles und erfülltes Leben führen. Die dramatischen Geschehnisse um die akute Rückenmarksverletzung mögen das Rampenlicht setzen; aber ein weit lohnenderes Drama setzt ein, wenn der Vorhang gefallen ist.

Acknowledgement. Grateful appreciation is extended to members of the medical staffs of St Joseph's Hospital and Medical Center and Good Samaritan Hospital for permission to report data pertaining to their cases.

\section{REFERENCES}

Frankel, H. L., Hancock, D. O., Hyslop, G., Melzak, J., Michaelis, L. S., Ungar, G. H., Vernon, J. D. S. \& Walsh, J. J. (I969). The value of postural reduction in the initial management of closed injuries of the spine with paraplegia and tetraplegia. Part I. Paraplegia, 7, I79-192.

Frankel, H., Michaelis, L. \& Paeslack, V. (I977a). Results of conservative treatment of extension rotation injuries of the cervical spine with tetraplegia. Proceedings of the Ninteeenth Veterans Administration Spinal Cord Injury Conference, Scottsdale, Arizona, I973, pp. 52-56.

Frankel, H., Michaelis, L., Paeslack, V., Ungar, G. \& Walsh, J. J. (I977b). Results of the conservative treatment of vertical compression injuries of the cervical spine. Proceedings of the Nineteenth Veterans Administration Spinal Cord Injury Conference, Scottsdale, Arizona, I973, pp. 28-32.

Paeslack, V., Frankel, H. \& Michaelis, L. (1977). Results of conservative treatment of flexion fractures and flexion rotation fracture dislocation of the cervical spine with tetraplegia. Proceedings of the Nineteenth Veterans Administration Spinal Cord Injury Conference, Scottsdale, Arizona, I973, pp. 39-42. 